\author{
岡 秀宏 ${ }^{1) 3)}$, Arie Perry ${ }^{2)}$, Bernd W. Scheithauer ${ }^{3)}$
}

1) 北里大学医学部脳神経外科, 2) Department of Pathology, University of California, San Francisco, U. S. A, 3) Departments of Laboratory Medicine \& Pathology, Mayo Clinic and Mayo Medical School, U. S. A

\title{
Treatment Strategy of Meningiomas based on the Pathological Diagnosis
}

\author{
Hidehiro Oka, M.D. ${ }^{1) 3)}$, Arie Perry, M.D. ${ }^{2)}$, and Bernd W. Scheithauer, M.D. ${ }^{3)}$
}

1) Department of Neurosurgery, Kitasato University School of Medicine, 2) Department of Pathology, University of California, San Francisco, U. S. A, 3) Departments of Laboratory Medicine \& Pathology, Mayo Clinic and Mayo Medical School, U. S. A

Meningioma is a meningothelial (arachnoidal) cell neoplasm, typically attached to the inner surface of the dura mater. Most meningiomas are benign and correspond to WHO grade I . Certain histological subtypes or meningiomas with specific combinations of morphologic parameters are associated with less favourable clinical outcomes and correspond to WHO grade II, including chordoid, clear cell, and atypical meningiomas, and grade III, including papillary, rhabdoid, and anaplastic meningiomas. The treatment strategy for meningiomas is total removal. While benign meningiomas have recurrence rates of about 7-25\%, WHO grade II meningiomas recur in $29-52 \%$ of cases and grade III meningiomas at rates of $50-94 \%$. Thus, radiotherapy for grade II and III meningiomas after tumor removal may be needed.

(Received September 24, 2012 ; accepted October 31, 2012)

Key words : meningioma, pathology, treatment, surgery, radiotherapy

Jpn J Neurosurg (Tokyo) $22: 90-95,2013$

\section{はじめに}

髄膜腫はくも膜表層細胞に由来し，硬膜の内側面に付 着して成長する腫瘍で，その大部分は良性腫瘍である。 その発生頻度は原発性脳腫瘍の $24 \sim 30 \%$ で最も頻度が 高( ${ }^{8)}$ 。この腫瘍は一般に成人（50 歳台にピークを有す る）に好発し，性差は男性：女性が 1:3.5 と女性に有意 に発生しやすい ${ }^{8)}$ 。この腫瘍は時に浸潤性発育や悪性化 することもあり，症例ごとに病理診断を正確に行い，治 療方針を決定する必要がある。

今回われわれは，この髄膜腫の病理診断に基づく治療 方針について解説する.

\section{成 因}

\begin{abstract}
髄膜腫は先に述べたように, くも膜表層細胞から発生 する脳実質外腫瘍であるが，発生原因については，不明 な点が多い。髄膜腫細胞の黄体ホルモンレセプターやエ ストロゲンレセプターの発現率が高いことから，女性ホ ルモンが関与しているとの考え方もある ${ }^{5)}$. また，他疾 患の治療目的で行った放射線治療が原因で髄膜腫が誘発 されることもある7 . 髄膜腫の遺伝子検索では 22 番染色 体の欠失が高頻度に認められ, 神経線維腫症 2 型の半数 例に䯣膜腫が多発性に発生することも周知の事実であ る。神経線維腫症 2 型は NF2 遺伝子の変異によって引 き起こされる疾患で，この疾患のない症例に発生した䯣
\end{abstract}

連絡先：岡 秀宏, $\bar{\top} 252-0374$ 相模原市南区北里 1-15-1 北里大学医学部脳神経外科

Address reprint requests to: Hidehiro Oka, M.D., Department of Neurosurgery, Kitasato University School of Medicine, 1-15-1 Kitasato, Minami-ku, Sagamihara-shi, Kanagawa 252-0374, Japan 
膜腫の約 $60 \%$ にF2 遺伝子の変異が認められる ${ }^{10)}$. ま た, この遺伝子異常は線維性髄膜腫や移行性䯣膜腫, 砂 粒腫性髄膜腫に頻繁に起こるとされている.

\section{病理分類}

髄膜腫は一般的には硬膜に広く付着して境界が明瞭な 塊状の病変を形成するが, 部位によっては扁平な板状の 病変を形成することもあり, en plaque meningioma と呼 ばれる。腫瘍の割面は, 灰白色で硬く弾力性があるが, 腫瘍に含まれる線維成分の量によって硬さは異なる ${ }^{8)}$.

WHO 分類は 2007 年に改訂され, 髄膜腫は meningeal tumours に分類されている ${ }^{8)}$. その亜型は grade I の 9 亜 型, grade II の 3 亜型, gradeIIIの 3 亜型に分類されてい る (Table 1)。髄膜腫の大部分は grade I で, grade II の髄 膜腫は全体の $4.7 \sim 7.2 \%$, gradeIII は 1.0 2.8\%の頻度に 過ぎない. 以下にそれらの亜型を示し, 解説する。すず ての腫瘍組織は誌面の関係上, 揭載できないため他の教 科書を参考にしていただきたい.

\section{WHO grade I の冎䐚膜腫と治療方針}

\section{Grade I：良性髄膜腫 ${ }^{8)}$}

\section{1) 咀道膜皮性䯣膜腫 (Meningothelial meningioma)}

䯣膜腫を代表するサブタイプ。腫瘍細胞は，円形〜楕 円形の核と広い好酸性の細胞質を有し, 細胞境界が不明 瞭で融合しているょうにみえる（Fig. 1A）。細胞が渦巻 き状に配列する whorl が特徵的で, 石灰化を示す砂粒体 が出現することも䯣膜腫の組織学的な特徵の一つであ る.

\section{2) 線維性髄膜腫（Fibrous meningioma）}

線維芽細胞に似た紡錘形の細胞の増殖からなり，腫瘍 細胞の間に膠原線維が多量に形成される腫瘍で, 線維成 分が多いため非常に硬い髄膜腫である (Fig. 1B).

3) 移行性髄膜腫 (Transitional meningioma)

髄膜皮性髄膜腫と線維性䯣膜腫の中間的な像を示す腫 瘍で，紡鍾形細胞が束状に並び，流れを形成するように 増殖する (Fig. 1C).

\section{4）砂粒腫性咀道膜腫 (Psammomatous meningioma)}

砂粒体が多数出現する腫瘍で, 春髄に発生しやすいこ とが特徴である（Fig. 1D）.

\section{5）血管腫性㵦膜腫（Angiomatous meningioma）}

大小不同の血管が多数増生しており，血管の間に髄膜 腫細胞が認められる髄膜腫で, 血管腫に類似した形態が 特徵である。
Table 1 Meningiomas（WHO 2007）

\begin{tabular}{l}
\hline Grade I \\
Meningothelial meningioma, Fibrous meningioma, \\
Transitional (mixed) meningioma, Psammomatous \\
meningioma, Angiomatous meningioma, Microcystic \\
meningioma, Secretory meningioma, Lymphoplasma- \\
cyte-rich meningioma and Metaplastic meningioma \\
Grade II \\
Chordoid meningioma, Clear cell meningioma and \\
Atypical meningioma \\
Gradelll \\
Papillary meningioma, Rhabdoid meningioma and \\
Anaplastic (malignant) meningioma
\end{tabular}

\section{6) 微小囊胞性髄膜腫 (Microcystic meningioma)}

腫瘍細胞間に大小の空胞あるいは囊胞様腔隙が認めら れ，実質が網目状構造を示す髄膜腫で（Fig. 1E），好酸 性硝子滴や脂質を取り込んで泡沫状の細胞質をもつ腫瘍 細胞もみられる。

\section{7）分泌性髄膜腫 (Secretory meningioma)}

好酸性円形の小体を入れた腺腔様構造が多数出現する 髄膜腫で, この小体は PAS 染色陽性で偽砂粒体 pseudopsammomatous bodies と呼ばれている. 電顕的所見で は微䋐毛を伴う小腺腔構造を形成しており, 分泌上皮へ の分化が明らかとなった髄膜腫といえる。

8）リンパ球・形質細胞に富む髄膜腫（Lymphoplasmacyte-rich meningioma)

高度の形質細胞・リンパ球浸潤と線維化を伴う髄膜腫 である。炎症性病変部と腫瘍実質の割合はさまざまで, リンパ球，形質細胞の浸潤が著しい場合，髄膜腫成分を 見出すことが難しい症例もある。炎症性偽腫瘍やロザ イ・ドルフマン病などと鑑別する必要がある。

9）化生性䯣膜腫 (Metaplastic meningioma)

間葉系細胞への分化を示す䯣膜腫で，骨・軟骨の形成 を伴うものや脂肪腫様変化, 黄色腫様変化, 粘液腫様変 化を示すものが含まれる.

WHO grade I の髄膜腫は放射線感受性が低いため，そ の治療方針は手術による腫瘍摘出を基本とする。摘出時 は腫瘍付着部硬膜も一緒に摘出することで再発率を下げ ることができる．頭蓋底発生等で付着部硬膜が摘出不可 能な場合は手術時に凝固処置を施す.残存腫瘍が増大し, 手術摘出困難な例では radiosurgeryも有効である。その 際，よく用いられる分類として Simpson grade ${ }^{9)}$ がある. これは, 腫瘍摘出を 5 段階に分類し，それらと術後 5 〜 20 年経過した時点での再発率を比較したものである. Grade 1 は付着した硬膜や近くの骨浸潤を含めた肉眼的 

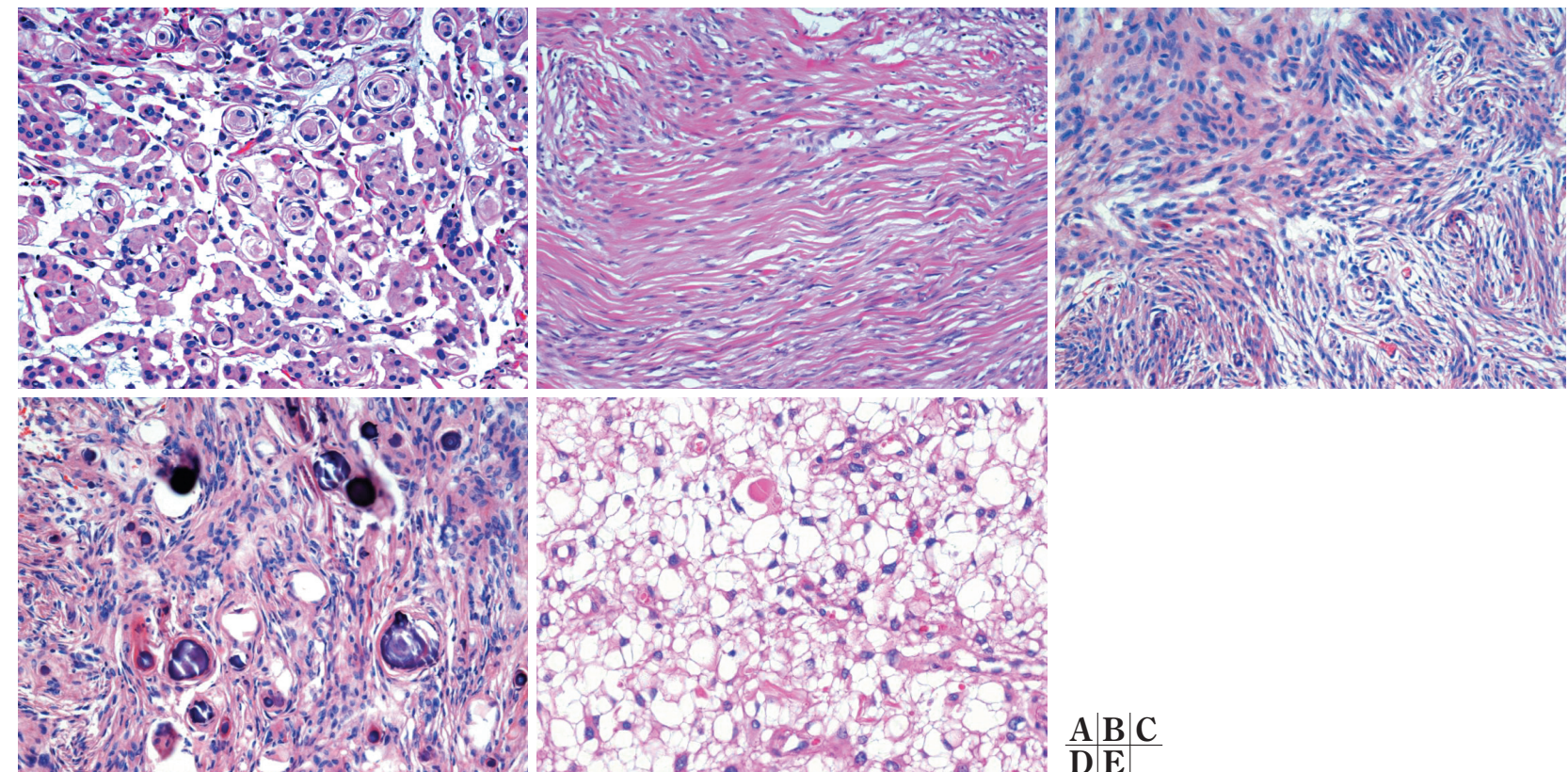

\begin{tabular}{l}
$A|B| C$ \\
\hline
\end{tabular}

Fig. 1 A : Meningothelial meningioma.

This tumor consists of what looks like normal arachnoid cap cells showing largely uniform cells with oval nuclei with delicate chromatin and many whorls.

B : Fibrous meningioma.

This meningioma variant consists of spindle cells forming parallel, storiform and interlacing bundles in a collagen-rich matrix.

C : Transitional meningioma.

This tumor variant shows coexisting meningothelial and fibrous patterns.

D : Psammomatous meningioma.

This variant of meningioma contains numerous calcified psammoma bodies along with an inconspicuous meningothelial component.

E : Microcystic meningioma.

This variant is characterized by cells with thin, elongated processes encompassing microcysts containing pale, eosinophilic mucinous fluid.

A

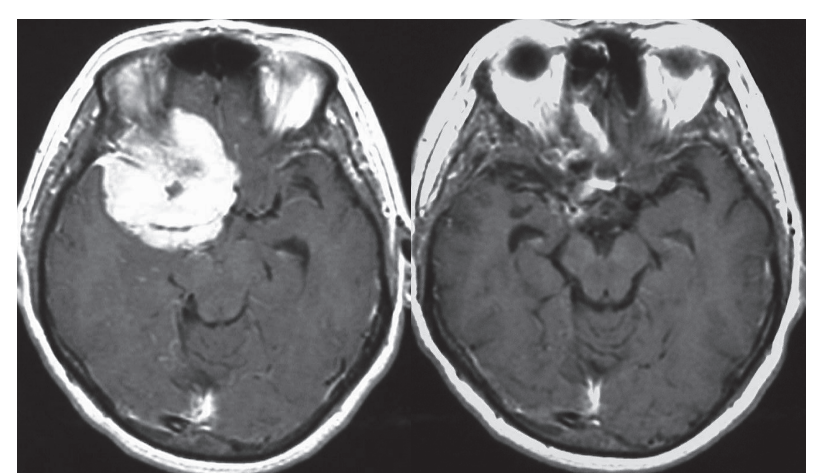

Fig. 2 A : A large sphenoid ridge meningioma encasing the ICA and MCA is revealed with Gd enhanced MRI.

B : The large tumor is completely removed by surgical procedure (Simpson grade 2).
全摘出が行われた場合, grade 2 は腫瘍の肉眼的全摘出と 付着した硬膜, 近くの硬膜浸潤部の凝固・焼灼, grade 3 は腫瘍の肉眼的全摘出のみ（凝固・焼灼を施していない もの), grade 4 は腫瘍の部分摘出のみ, grade 5 は腫瘍部 の生検・減圧手術のみ，の場合である。それぞれの再発 率は grade 1 で $9 \%$ ，2 で $19 \% ， 3$ で $29 \% ， 4$ で $44 \%$ と なり, grade 5 では腫瘍が摘出されていないため, 残存腫 瘍がほぼ $100 \%$ となる。WHO grade I の場合は，先に述 べたように基本的に全摘出を目指す必要があるが，頭蓋 底部に発生した場合や，神経・血管系に強く癒着する症 例などでは, Simpsonの grade 1 に達しない場合がある. その際は極力 grade 2 を目指し，経過観察をする（Fig. $2 A ， B)$ 。髄膜腫に対する放射線分割外照射により，増殖 抑制効果および生存期間延長をもたらすことが報告され ている ${ }^{3)}$ が，早期の放射線治療は誘発性腫瘍，放射線壊 死，下垂体機能低下等の副作用を考慮し控える必要があ る ${ }^{1)}$ 。ただし, 経過観察で腫瘍増大を認め, 再発腫瘍の 


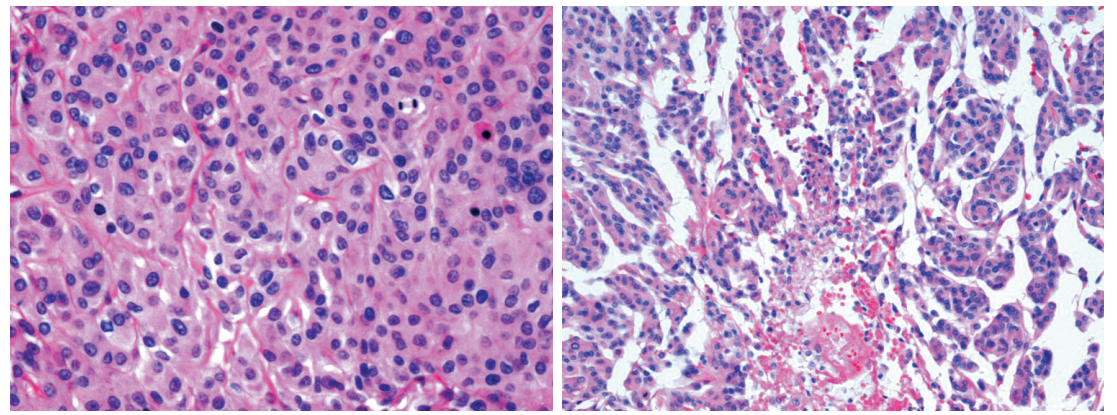

Fig. 3 Atypical meningioma

A meningioma with increased mitotic activity or three or more of the following histologic features: increased cellularity, small cells with a high nuclear to cytoplasm ratio, prominent nucleoli, uninterrupted patternless or sheet-like growth (A), and foci of "spontaneous" or "geographic" necrosis $(\mathbf{B})$.

摘出を行っても取りきれない場合は，再発により悪性度 が上がることも考慮し, 残存部に放射線治療を施行する. このような場合は，分割外照射より，周囲脳への放射線 の影響を軽減するため定位放射線治療が行われることが 多い. 特に, 八イリスク患者, 高齢者で手術が困難な場 合や, 頭蓋底髄膜腫の残存腫場がよい適応となる。

\section{WHO grade II の䯣膜腫と治療方針 \\ Grade II：中間悪性髄膜腫}

\section{1）異型性髄膜腫（Atypical meningioma）}

高い細胞分裂能を示す髄膜腫（Fig. 3A）, あるいは, 腫瘍細胞の密度の上昇, 核/細胞質比の高い小型細胞の巣 状の出現, 明膫な核小体, 配列の特徵がない一様なシー 卜状の増殖, 自然発生的あるいは地図状壊死巣 (Fig. 3B) の 5 個の特徵のうち 3 個以上あるものを指す。分裂能は 通常は核分裂指数（強拡大 10 視野あたりの核分裂像の 数）で表され，高い細胞分裂能を示す髄膜腫とは，核分 裂指数が 4 個以上のものを指している。しばしば脳実質 への浸潤を伴う。

\section{2) 明細胞髄膜腫 (Clear cell meningioma)}

グリコーゲンを多量に含んでいるため, 細胞質が明調 に見える腫瘍細胞の増殖からなる髄膜腫である．細胞間 に硝子化した間質線維が小さな塊を形成して出現するこ とも特徵の一つである. 腰髄硬膜下や小脳橋角部に発生 しやすく, 頭蓋内に発生するものは再発や播種を起こし, 悪性の経過をたどることもある.

3）脊索腫様喵道膜腫 (Chordoid meningioma)

粘液様基質内に腫瘍細胞が上皮様の索状構造を形成し て増殖する髄膜腫で, 骨に発生する脊索腫に類似してい るため,このように命名された。
A

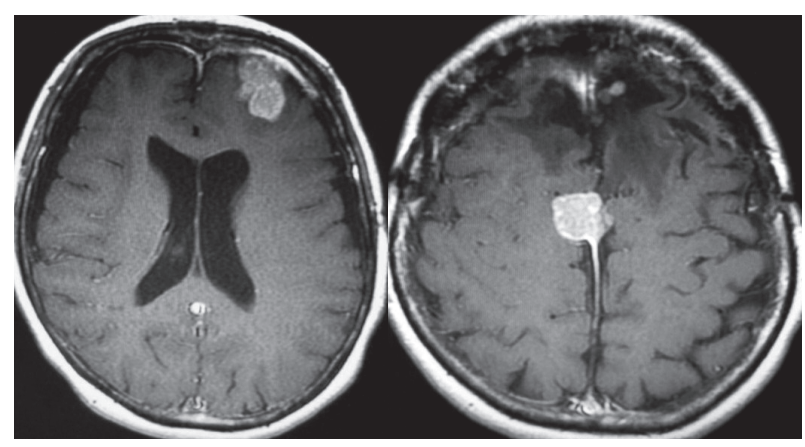

Fig. 4 MRIs with Gd-DTPA showing a recurrent tumor arising from the left frontal convexity (A) and falx (B) after removal of an atypical falx meningioma.

WHO grade II の髄膜腫の治療方針も I 同様に，まずは 手術的に腫瘍全摘出を目指すことが必要である。Simpson grade で 1 2 であれば基本的に経過観察し, grade 3〜5ではその悪性度に応じ, 再発・再増大時に手術摘出 と定位放射線治療を含む放射線照射が必要になることが 多い6). しかし，最新の報告では grade II の全摘出後に放 射線照射をすることにより，再発率低下に寄与したとの 報告もある ${ }^{4)}$. Grade II では I と異なり硬膜・脳への浸潤 性性格が強くなるので, 手術摘出のみでは再発率が高く, 再発を見逃さないように十分な経過観察が重要である (Fig. 4A, B). 

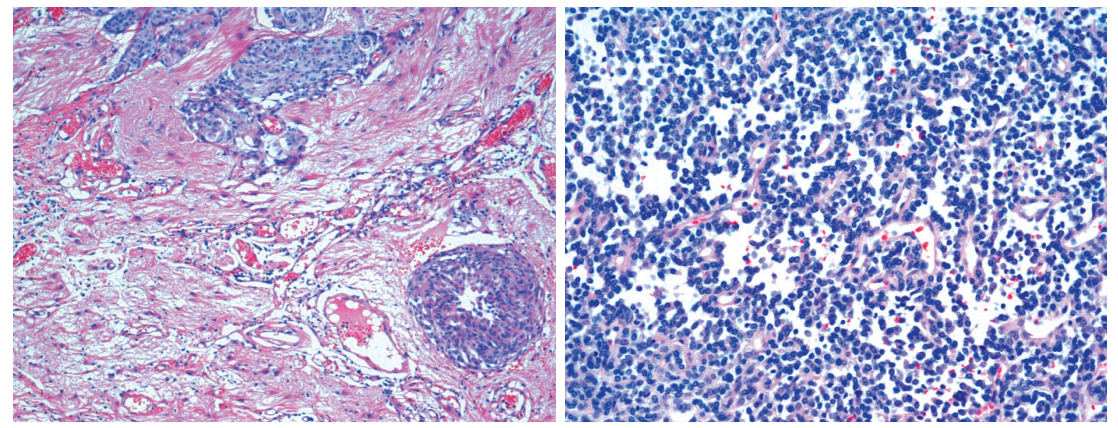

$\mathbf{A} \mid \mathbf{B}$

Fig. 5 A : Anaplastic meningioma.

Anaplastic meningiomas exhibit histological features of frank malignancy far in excess of the abnormalities present in atypical meningiomas. Brain invasion is observed (A).

B : Papillary meningioma.

This is a rare meningioma variant that presents a perivascular pseudopapillary pattern containing the majority of the tumor.

A

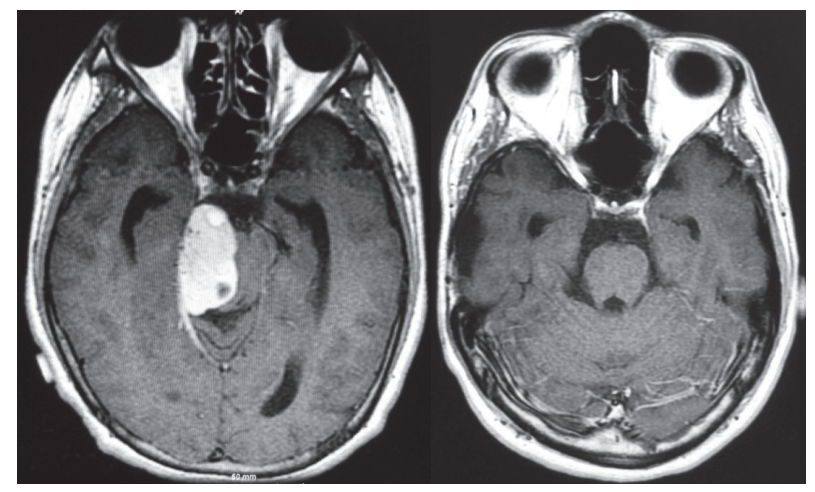

Fig. 6 MRI of 13-year-old boy demonstrating a right tentorial papillary meningioma $(A)$ with hydrocephalus. The tumor has not shown recurrent tumor after total surgical removal and radiotherapy $(\mathbf{B})$.

\section{WHO grade IIIの䯣膜腫と治療方針}

\section{Grade III：悪性髄膜腫}

1）退形成性（悪性）䯣膜腫 (Anaplastic [malignant] meningioma)

異型性髄膜腫にみられるような異常所見がより顕著 で，明らかな悪性の組織学的特徵を示す䯣膜腫を指す。 肉腫や癌, 覀性黒色腫に類似した高度の細胞異型を示す もの，あるいは増殖能が異常に高く核分裂指数が 20 個 以上に達するものとされている。しばしば広い壊死巣や 脳浸潤（Fig. 5A）が形成される.

\section{2）乳頭状㵦膜腫（Papillary meningioma）}

腫瘍細胞が血管周囲に偽乳頭状に配列し（Fig. 5B）, 増殖する領域が認められる髄膜腫である。鑑別として胃
癌や大腸癌，腎癌の転移および脈絡叢癌，退形成性上衣 腫等が挙げられる，同時に存在している䯣膜腫要素は豊 富な核分裂像，壊死，局所浸潤など悪性を示唆する所見 を示す，小児に発生しやすく，通常の髄膜腫より若年者 に発生する (Fig. 6A，B）。

\section{3）ラブドイド髄膜腫（Rhabdoid meningioma）}

ラブドイド細胞が出現する髄膜腫で，通常の髄膜腫要 素と一緒にラブドイド細胞からなる領域が出現するもの とラブドイド細胞のみからなるものがある。ラブドイド 細胞は小児の腎臟に発生する悪性ラブドイド腫瘍で定義 された特徵的な形態を示す細胞で，その特徵は核小体が 明瞭な類円形の核が細胞質の一側に偏っており, 細胞質 は好酸性で円形の封入体様構造を示すことである。

WHO gradeIIII髄膜腫の治療方針も I , II 同様に，ま ずは手術的に腫瘍全摘出を目指すことが必要である. Simpson grade 1 3 では初回腫瘍摘出後に腫瘍付着部を 含めやや広い照射野での分割照射が必要になることが多 い. Grade 4〜5 の場合は経過観察により悪性髄膜腫の急 速増大を認める可能性があるため，放射線治療（定位放 射線あるいは分割照射）を施行せざるをえない場合が多 い6). GradeIIIでは II 以上に硬膜・脳への浸潤性性格が強 くなるので, 初回手術摘出後に放射線治療が必要とな $ろ^{6)}$.

化学療法は効果的なものは少ないが近年では再発を繰 り返す髄膜腫に分子標的薬として somatostatin, PDGF (imatinib), EGF (erlotinib), VEGF (sunitinib, vatalanib) を使用した報告もある ${ }^{2)}$ が，現時点では手術摘出と放射 線の組み合わせが重要である. 


\section{予 後}

再発の頻度は腫瘍摘出の程度に影響され, 良性髄膜腫 で完全に摘出されれば，治癒が見込まれるが，一部は数 年後再発することがある. 組織学的な grade 分類が再発 を予測するよい指標となり，良性髄膜腫； grade I で 7〜 25\%, 異型性髄膜腫; grade II で 29 52\%, 退形成性髄 膜腫； gradeIIIで 50～94\%が再発するとされている ${ }^{8)}$.

\section{結 論}

すべての髄膜腫治療は手術的に腫瘍を摘出することが 基本であるが, grade や再発状況, 浸潤性格, 悪性化を 病理学的に診断したうえで治療方針を決定することが重 要である.

\section{文 献}

1) al-Mefty O, Kersh JE, Routh A: The long-term side effects of radiation therapy for benign brain tumors in adults. J Neurosurg $73: 502-512,1990$.

2) Chamberian MC, Barnholtz-Sloan JS: Medical treatment of recurrent meningiomas. Expert Rev Neurother 11: 1425-1432, 2011.
3) Condra KS, Buatti JM, Mendenhall WM: Benign meningiomas: primary treatment selection affects survival. Int J Radiat Oncol Biol Phys 39: 427-436, 1997.

4) Komotar RJ, Iorqulescu JB, Holland EC, Beal K: The role of radiotherapy following gross-total resection of atypical menigiomas. J Neurosurg 117: 679-686, 2012.

5) Korhonen K, Salminen T, Raitanen J, Auvinen A, Isola J, Haapasalo $\mathrm{H}$ : Female predominance in meningiomas can not be explained by differences in progesterone, estrogen, or androgen receptor expression. J Neurooncol $\mathbf{8 0}: \mathbf{1 - 7}$, 2006.

6) Modha A, Gutin PH : Diagnosis and treatment of atypical and anaplastic meningiomas: A review. Neurosurgery 57: 538-550, 2005.

7) Musa BS, Pople IK, Cummins BH: Intracranial meningiomas following irradiation-a growing problem? Br J Neurosurg 9:629-637, 1995.

8) Perry A, Louis DN, Scheithauer BW, Budka H, von Deimling A: Meningioma. in Louis DN, Ohgaki $\mathrm{H}$, Wiestler OD, Cavenee WK (eds) : WHO Classification of Tumours of the Central Nervous System 3rd edition. Lyon, WHO Press, 2007, pp164-172.

9) Simpson D: The recurrence of intracranial meningioma after surgical treatment, J Neurol Neurosurg Psychiatry 20:22-39, 1957.

10) Trofatter JA, MacCollin MM, Rutter JL, Murrell JR, Duyao MP, Perry DM, Eldridge R, Kley N, Menon AG, Pluaski $\mathrm{K}$ : A novel moesin-, ezrin, radixin-like gene is a candidate for the neurofibromatosis 2 tumor suppressor. Cell 72: 791-800, 1993.

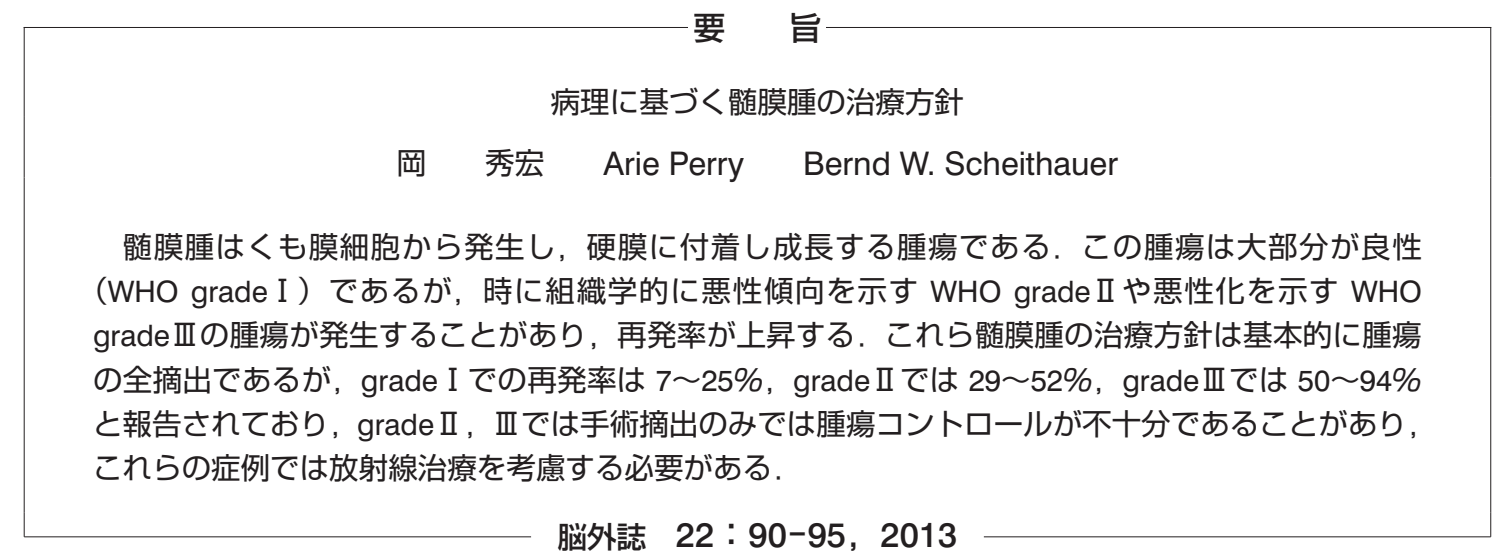

